which they might seriously disturb the whole domestic economic machine, there would be substantial cause for forebodings and for precautionary measures. But the payments of principal will be met by Europe only if spread over a long period of time-if it is not undue optimism to expect that they will not have to be largely written off as bad debts. If anything is to be feared during the next decade, it must be the interest payments. These, while substantial enough if fully paid, are but a small fraction of the annual output of American industry, and not great enough to disturb the smooth working of a great economic system, resting on solid foundations.

The policy of the government will be decided by the victor in the clash of group interests. Were political conditions now what they were before 1914, it would be a safe prediction that the manufacturers would have their own way. They are now divided among themselves, however, and the farmers are much better organized than they ever were before. It is in the general interest that the efforts of the exporting manufacturers to check restrictive legislation shall be successful. It would be, however, the irony of fate if the rôles of beneficiary and victim should now be reversed, and if the tariff, which for almost a century the manufacturers imposed on the farmers to the benefit of the former and to the injury of the latter, should now turn upon the manufacturers and force them to give largesse to the farmers.

\title{
The Effect of Depreciated Exchange on Foreign Trade
}

\author{
By O. M. W. Sprague, Ph.D. \\ Harvard University Graduate School of Business Administration
}

$I^{\mathrm{N}}$ $\mathrm{N}$ the conduct of business many unavoidable risks are encountered. To perceive the risks that must be incurred is much, but it is also of vital importance to understand their nature and probable consequences. Risks which are perceived but not understood are altogether likely to become the foundation for exaggerated fears. This seems to be the present situation as regards the probable consequences of depreciated foreign exchange rates upon both the export and the import trade of the United States.

Stated in summary fashion, the reasoning which forecasts disastrous results to the foreign trade of the country from depreciated exchange rates runs somewhat as follows: With sterling at $\$ 4.00$ it is argued that the British producer can sell at a good profit in the United States goods which could not be profitably marketed here with sterling at par, i.e., at $\$ 4.86$. At the depreciated rate, he will receive on the sale of goods for $\$ 1,000$ in the United States £250 instead of the £210 which he would have secured when exchange was at par. Here would indeed appear to be a prodigious stimulus to the export business of a country on a depreciated basis, and also a similarly great obstacle to imports.

But this is not the whole story. That there must be counteracting influences at work is to be presumed from the absence of any instance of extraordinary increase in exports and decline in imports in the case of countries which in the past have gone upon an inconvertible basis. ${ }^{1}$ Consideration of

\footnotetext{
${ }^{1}$ The experience of European countries since the war is, of course, too short to provide an adequate basis for conclusion on this matter.
} 
the conditions which lead to a departure from the gold standard will at once make clear the character of these counteracting influences. A country goes upon an inconvertible basis ordinarily because it is experiencing untoward influences which, among other things, have tended to stimulate imports and to check its normal export business. Depreciated exchange rates serve in large measure to counteract influences which have already brought the trade of a country into an abnormally unfavorable condition. If, for example, sterling were now at par, the British producer could not realize a profit from goods which he formerly sold in foreign countries. Inflation of domestic prices and the consequent increase in money costs have preceded depreciation. If money costs had remained unchanged, there would have been no depreciation or at least only for a short period of time.

The particular unfavorable influences which have occasioned depreciation vary greatly in the different countries which have found themselves unable to maintain the gold standard. Taking the many countries now on an inconvertible basis, we find that ability to produce in all of them has been in varying degree unfavorably affected by the war. There has also been a marked decline in the accustomed demand for the staple products of many countries which were not engaged in the war. The European demand for most South American products may be cited as an example. More important, at least immediately, has been the currency and credit inflation during and since the war. The extent of such inflation has been almost in direct ratio with the economic and financial difficulties of the various countries. The depreciation of the franc, for example, to about one-third of its pre-war value reflects the far greater inflation and industrial difficulties of France as contrasted with those of Great Britain, the currency of which has depreciated by only about 25 per cent.

Expressed somewhat abstractly, it may be said that depreciated exchange has no effect whatever on the imports or the exports of a country after a condition of fairly stable depreciation has been reached. If, for example, the pound sterling were closely to approximate $\$ 3.75$ for a number of years, neither the imports nor the exports of Great Britain would be appreciably different from what they would have been in the absence of depreciation. The only essential difference would be that the general level of domestic prices measured in the depreciated currency would be some 25 per cent above what it would have been with exchange at par. It is only the fluctuations in exchange rates (and depreciated exchange fluctuates widely) that have a specific influence on foreign trade. If, for any reason, rates decline more than the coincident inflation in prices, and decline in industrial efficiency, exports will be stimulated and imports curtailed. An advance in rates is then certain in no short period of time, unless the condition of the country is going from bad to worse. Such a temporary decline in exchange, going beyond the difficulties of the situation, seems to have occurred in the case of sterling, when early in 1920 it declined to $\$ 3.18$ and shortly thereafter rose to the vicinity of $\$ 4.00$.

Wide and unforeseen fluctuations in exchange of this character, while they may at times stimulate exports, exert upon the whole a far from favorable influence on the development of the trade of a country. Intermittent ability to supply goods in foreign markets is not conducive to healthy development. For countries engaged largely in the manufacture of goods in 
the production of which imported materials are used, the consequences of widely fluctuating exchange rates are apt to prove particularly disturbing. In the event that exchange rates rise between the date of purchase of the material and the date of sale of the finished product, losses, and often very serious losses, are incurred. Many producers on the continent of Europe, for example, had a costly experience with the vagaries of depreciated exchange in the summer of 1920, when there was a decided though temporary advance in the rates of exchange on the United States.

Depreciated paper exchange never furnishes examples of the prolonged stimulus to export business which have occasionally been present in the case of the silver-using countries as a result of falling silver prices. The price of silver may decline quite independently of conditions affecting money costs of production in a particular silver-using country. Producers in the silver-using country then reap large gains from export business until finally wages and other domestic money costs advance. As wages in the silver-using countries are strongly influenced by custom and change slowly, the stimulating effect of a fall in the price of silver may last for a considerable period of time. A decline in paper exchange is not analogous because it is never due primarily to influences external to the country which is on an inconvertible basis. The decline, as has been before observed, mainly reflects conditions which have already developed in the country itself. Even if the decline in exchange more than discounts these conditions, the advantage to those engaged in production for export will be far more temporary than in the case of the silver-using countries, because in the western world wages and other money costs more speedily adjust themselves to monetary changes.

It usually happens that a country which is on a depreciated paper basis is in need of far more capital than is currently provided by domestic savers. It endeavors to secure capital from foreign countries. But the very fact that exchange has depreciated, and that consequently the annual return from capital when converted into foreign currency is subject to variation on account of fluctuation in exchange, is a serious obstacle to the acquisition of foreign capital in large amounts and at reasonable rates. In so far then as the industrial development of a country and so its export business might be quickened by the investment of foreign capital, depreciated inconvertible paper money exerts an unfavorable influence.

It is not improbable that the export trade of the United States in the next few years will be considerably less than it has been since the outbreak of the European War. Many influences are present which seem bound to exert an unfavorable influence upon that trade. Depreciated exchange is not, however, one of those influences. In fact, if the European countries steadily put into effect the measures necessary to restore their currencies to pre-war parities, exports to the United States will undoubtedly be far more considerable than is at all likely to be the case if something like the present situation continues. In order to return to the gold standard at pre-war parities it will be necessary for the European countries to contract credit, curtail governmental expenditures, balance governmental expenditure and revenue, increase industrial efficiency, develop. foreign markets to a greater extent than before the war, and also curtail in every possible way imports of unnecessary articles of consumption. The contrary policy of allowing mat- 
ters to drift can hardly fail to involve a continuance of present depreciated rates and perhaps a further decline. Occasionally, extreme declines will temporarily make possible the exportation of goods not regularly exported, but the general tendency will certainly be for both the export and the import business of Europe to fall away, re- flecting continued industrial and financial decay.

Depreciated exchange is not a corrective; it is merely a symptom of an unhealthy condition. It consequently does not subject producers in this country to abnormal foreign competition from which they might reasonably ask to be shielded by legislation.

\title{
The Part of Direct Exporting in the Future of American Industry
}

\author{
By Henry H. Morse \\ Chairman, Boston Export Round Table \\ and \\ Walter F. Wyman \\ Honorary Chairman, Boston Export Round Table
}

$\mathrm{T}_{\text {XPORT trade is the one adequate }}$ which owe their being to American brains and American labor. Those careful students of commerce whose vision has been so largely responsible for our domestic development are today found to be turning their eyes overseas. The law of diminishing returns is already curtailing the potential profits in many lines whose marketing has been confined within our boundaries. It is not necessary for a saturation point to be visible for it to exist. The fact that there is a definite saturation point which is only beyond the range of direct vision is the compelling force which is leading American industry into scientific direct exporting.

With the shortening distances due to improved methods of transportation; with the growing acceptance of higher standards of living; with the widening circle of demand for comfort, convenience and luxury as well as mere existence, the once limited field of many American industries has broadened to permit economical merchandising of
American product in foreign lands. In the rapid development of labor-saving machinery the possibilities of production have increased in mathematical progression in comparison to the increased consumer demand of the domestic market. The principles of mass merchandising as well as the principles of mass production are today understood, where two decades ago both were unknown. Due to the sudden demands of the World War, manufacturing capacity was increased overnight to a point far beyond the natural growth of several decades.

So we have on one hand a new consumer acceptance in foreign lands which is rapidly growing to definite consumer demand, not only for a widening variety of American-made merchandise but also for decidedly increased quantities of American-made merchandise. On the other hand, we have for the first time both the desire and the necessity for a wider market than even the increased population of the United States provides.

To a great extent the market beyond 